Ismailova S.R.*

DOI: 10.25108/2304-1730-1749.iolr.2020.62.105-118

UDC 341.4

\title{
Cooperation in the system of existence
}

Abstract: A structure of the system of cooperation consists on the subjects, objects and correlation between them. Subjects include individuals and legal entities, associations (formations) that have no the status of legal entities, state, non-governmental, public or private organizations and institutions, states, their bodies, etc.

Objects of cooperation are kinds and products of human activity, and correlations are informational communications between the subjects of cooperation.

The essence of cooperation is the exchange and use of information to solve political, military, economic, ideological, cultural, social and other issues of human life that are of interest to its participants.

Communication is an effective synchronous and diachronic interaction, the purpose of which is to transfer information from one subject to another.

In terms of the number of participants, cooperation can be multilateral and bilateral, and according to the territorial principle - global, supra-regional, regional and bilateral.

The legal basis for cooperation is contracts (bilateral or multilateral, terminable or permanent) or one-time contacts (appeals) of parties not obliged by the contracts.

We consider the problem of cooperation in the field of human rights in a "pure" form, not burdened by other goals and objectives of its participants, although a similar approach is conditional. Cooperation in the field of human rights, as a rule, together with the declared goal of protecting and observing human rights, has other roots that go back to the political, economic, military and other more global interests of the participants, which sometimes do not appear among the persons involved in cooperation.

In its ideal form, cooperation is defined as a system of cooperative interaction of subjects and objects of coexistence and communication between them, aimed at achieving a common goal.

Keywords: interaction; collaboration; cooperation; conflict; communication; information.

\section{References}

1. Ananiev B.G. Chelovek kak predmet poznaniya [Human as a subject of cognition]. Leningrad, Leningrad University Publ., 1968, 343 p.

2. Andreeva G.M. Sotsial'naya psikhologiya: Uchebnik [Social psychology. Textbook]. Moscow, Aspect Press Publ., 2001, 384 p.

3. Aristotle. Fizika [Physics]. Moscow, Direct-Media Publ., 2012, 191 p.

4. Asmus V.F. Antichnaya filosofiya (istoriya filosofii). 3-e izd. [Antique Philosophy (History of Philosophy) 3d edition]. Moscow, Vysshaya shkola Publ., 2003, 400 p.

\footnotetext{
- Ismailova Sevinj Rauf qizi - Doctoral Candidate of the Academy of Public Administration under the President of Azerbaijan Republic, PhD in Law, Azerbaijan. E-mail: sevism@ rambler.ru
} 
5. Baburin C.P. Mir imperiyi: Territoriya, gosudarstva i mirovoyi poryadok [World of Empires: Territory, states and global order]. S. Petersburg, R. Aslanov and Yuridicheskiyi Center Press Publ., 2007, 769 p.

6. Batalov E.Ya. O filosofii mezhdunarodnykh otnosheniyi [On philosophy of international relationships]. Moscow, Nauchno-obrazovatel'ny forum po mezhdunarodnym otnosheniyam, 2009, $132 \mathrm{p}$.

7. Bodalev A.A. Lichnost' $i$ obshenie [Personality and intercommunication]. Moscow, Mezhdunarodnaya pedagogicheskaya akademiya Publ., 1995, 328 p.

8. Blumer G. Simvolichesky interaktsionizm. Per. s angl. A.M. Korbut [Symbolic interactionism. Transl. from Eng. by A.M. Korbut]. Moscow, Elementarnye formy Publ., 2017, 346 p.

9. Gavra D.P. Osnovy teorii kommunikatsii. Uchebnik dlya akademicheskogo bakalavriata. 2-e izd., ispr. i dop. [Basis of theory of communication. Textbook for bachelors, 2 edition, rev. and suppl.]. Moscow, Yurayit Publ., 2017, 282 p.

10. Gaynullina A.V. K voprosu o ponyatii vzaimodeyistviya v otechestvennoi psikhologii [To an issues on notion of interaction in domestic psychology]. Yuridicheskaya psikhologiya-Legal Psychology, 2007, no. 3, pp. 18-21.

11. Gegel G. Nauka logiki v 3 tomakh. T. 2 [Science of logics in 3 vol. V. 2]. Moscow, Mysl Publ., 1971, 248 p.

12. Grigoryeva M.V. Vzaimodeistvie kak kategoriya sovremennoi psikhologii [Interaction as a category of modern psychology]. Uchennye zapiski. 2009. Vol. 2. Ser. Psikhologiya. Pedagogika. No. 3-4 (7-8), pp. 3-12.

13. Grin I.Yu. Mezhdunarodnoe sotrudnichestvo $v$ sfere ugolovnogo sudoproizvodstva. Dis...kand. yurid. nauk [International cooperation in the field of criminal proceeding]. PhD in Law Diss. S. Petersburg, 2006, 165 p.

14. Gromkova M.T. Psikhologiya i pedagogika professional'noi deyatel'nosti. Uchebnoe posobie [Psychology and pedagogic of professional activity. Teaching handbool for Universities]. Moscow, Yuniti-Dana Publ., 2003, 415 p.

15. Declaration on principles of international law friendly relations and co-operation among states in accordance with the Charter of the United Nations of 24.10.1970 . Available at: https://www.un.org/ru/documents/decl_conv/declarations/intlaw_principles.shtml (accessed 18.02.2020) (in Russian)

16. Dolenko D.V. Sovremennya mirovaya politika. Uchebnoe posobie [Modern global policy. Teaching handbook]. Saransk, Mordov University Publ., 2005, 176 p.

17. Zelenkov M.Yu. Politologiya (bazovyi kurs) [Political Science (basic course)]. Moscow, Yuridichesky Institute Publ., 2009, 302 p.

18. Inozemtsev V.L. Rossia v sisteme mezhdunarodnykh otnosheniyi XXI veka [Russia in the system of international relations of 21 century]. Mezhdunarodnaya zhizn' - International life, 2004, no. 9-10, pp. 3-19.

19. Istoria mezhdunarodnykh otnosheniyi i vneshneyi politiki SSSR $\mathrm{v} 3$ tomakh [History of international relations and foreign policy of USSR in 3 Vol.] Ed. by I.A. Kirillin. Moscow, Mezhdunarodnye otnoshenia, 1986, $416 \mathrm{p}$.

20. Kagan M.S. Mir obschenia: problemy mezhsub'yektnykh otnosheniyi [World of intercommunication: problems of inter-subject relations]. Moscow, Politizdat Publ., 1988, 319 p. 
21. Kazarinov N.V., Kunitsin V.N., Pogolsha V.M. Mezlichnostnoe obschenie. Uchebnik dlya vuzov [Inter-personal intercommunication. Textbook for Universities]. S. Petersburg, Piter Publ., 2001, 544 p.

22. Kant E. Sochineniya v shesti tomakh. T. 3 [Collection works in 6 vol. V. 3]. Moscow, $1964,799 \mathrm{p}$.

23. Kemerov V.E. Vzaimodeistvie.Tsentr gumanitarnykh tekhologii [Interaction. Center of Humanitarian technologies]. Available at: https://gtmarket.ru/concepts/7242 (accessed 18.02.2020)

24. Kolominsky Ya.L. Izuchenie pedagogicheskogo vzaimodeistviya [Studying of pedagogic interaction]. Sovetskaya pedagogika-Soviet pedagogic, 1991. No. 10, pp. 36-42.

25. Kosolapov N.A. Issledovanie mezhdunarodnykh otnosheniyi, logika ideyi, intersov, politiki [Researching of international relationships, logics of ideas, interests, policy]. Mirovaya ekonomika $i$ mezhdunarodnye otnosheniya - Global economics and international relationships, 2006. No. 2, pp. 93-99.

26. Kosolapov N.A. Teoreticheskoe issledovanie mezhdunarodnykh otnosheniyi [Theoretical researching of international relationships]. Mirovaya ekonomika i mezhdunarodnye otnosheniya Global economics and international relationships, 1998. No. 2, pp. 67-79.

27. Krivolapov P.S. Hovye tendentsii mezhdunarodnogo sotrudnichestva v oblasti prav cheloveka. Diss... kand. yurid. nauk [New trends of international cooperation in human rights field]. $\mathrm{PhD}$ in Law Diss. Moscow, 2006, 213 p.

28. Krichevsky R.L., Dubovskaya E.M. Sotsial'naya psikhologiya maloyi gruppy. Uchebnoe posobie dlya vuzov [Social psychology of small group. Teaching aid for Universities]. Moscow, Aspect-Press Publ., 2001, 318 p.

29. Kuznetsova E.S. Mirovaya politika $i$ bez. Analiz $i$ prognoz $v$ mezhdunarodnykh otnosheniyakh [Global policyand without. Analysis and forecast in international relationships]. Mezhdunarodnya zhizn - International life, 2006. No. 1-2, pp. 94-105.

30. Kurbanov R.O. Kategoriya vzaimodeyistviya v filosofskom i nauchnom poznanii. Avtoref dis...dokt. filos. nauk [Category of interaction in philosophical and scientific cognition]. Doctor of Philosophy Diss. Abstract. Baku, 1989, 52 p.

31. Lanko D.A. Problema sotrudnichestva v tret'em "bol'shom spore" v teorii mezhdunarodnykh otnosheniyi [Problem of cooperation in the third 'great dispute' in theory of international relationships]. Vestnik S. Peterburgskogo universiteta-Gerald of Petersburg University, 2013. Ser. 6. Iss. 2, pp. 92-97.

32. Levin K. Dinamicheskaya psikhologiya/per. s nem. i angl. [Dynamic Psychology. Transl. from German and English] by D.A. Leontyev, E.Yu. Patyaeva. Moscow, Smysl Publ., 2001, 572 p.

33. Levchenko O.V., Mischenko E.V. Mezhdunarodnoe sotrudnichestvo Rossii s gosudarstvami-uchastnikami SNG v sfere ugolovnogo sudoproizvodstva: ponyatie, tseli, printsipy [International cooperation of Russia to the states-participants of CIS in an area of criminal proceedings: notion, goals, principles]. VestnikVGEU-Gerald of VGEU, 2014, No. 6(74), pp. 38-48.

34. Leontyev A.A. Pedagogicheskoe obschenie [Pedagogical intercommunication]. Moscow, Znanie Publ., 1979, 48 p.

35. Lisina M.I. Problemy ontogeneza obscheniya [Problems of ontogenesis of intercommunication]. Moscow, Pedagogy Publ.,, 1986, 144 p.

36. Lomov B.F. Metodologicheskie i teoreticheskie problemy psikhologii [Methodological and theoretical problems of psychology]. Moscow, Nauka Publ., 1984, 444 p. 
37. Malko A.V., Shundikov K.V. Tseli $i$ sredstva v prave $i$ pravovoyi politike [Goals and means in law and law policy]. Saratov, SGAP Publ., 2003, 296 p.

38. Malkova T.P., Frolova M.A. Massy. Elita. Lider [Masses, Elite, Leader]. Moscow, Znanie Publ., 1992, 40 p.

39. International law aid and other forms of cooperation between law enforcement agencies. OECD, 2013. Available at: https://www.oecd.org/corruption/acn/lawenforcement/ MLAand OtherFormsCooperationLawEnforcementAgencies_RUS.pdf (accessed 18.02.2020) (in Rus.).

40. Mezhdunarodnye otnosheniya: teoriya, konflikty, organizatsii. Ucheb.posobie; pod red. Prof. P.A. Tsygankova [International relationships: theory, conflicts, organizations. Teaching aid; ed by Prof. P.A. Tsygankov]. Moscow, Alfa Publ., 2004, 288 p.

41. Mezhdunarodnye otnosheniya: vidy, formy, printsipy [International relationships: types, forms, principles]. Available at: https://works.doklad.ru/view/RgPucar6CdU.html (accessed 14.02.2020).

42. Mid G.G. Izbrannye [Selected works]. Comp. and transl. by V.G. Nikolayev; ed. by D.V. Efremenko. Moscow, RAN INION Publ., 2009, 290 p.

43. Morozov V.A. Vzaimodeystvie: ponyatie, vidy i svoyistva [Interaction: notion, types and features]. Kreativnaya ekonomika - Creative economics, 2015, no. 9(10), pp. 1309-1318

44. Myasischev V.N. Psikhologiya otnosheniyi [Psychology of relationships]. Moscow, Institute prakticheskoyi psykhologii Publ., 1995, 356 p.

45. Natura A.I., Pikhov A.H-A. Mezhdunarodnoe sotrudnichestvo v sfere ugolovnogo sudoproizvodstva: organizatsionno-pravovye osnovy, protsessual'nyi poryadok i formy vzaimodeyistviya [International cooperation in sfere of criminal proceedings: organizational and legal basis, procedural order and forms of interactions]. Uchebno-praktich. posobie. Moscow, Yurlitiform Publ., $2007,136 \mathrm{p}$.

46. Obozov N.N. Psikhologiya mezhlichnostnykh otnosheniyi [Psychology of interpersonal relationships]. Kiev, Lybid Publ., 1990, 192 p.

47. Obschie voprosy. Mezhdunarodnoe sotrudnichestvo. Posobie po otsenke sistem ugolovnogo pravosudiya [General Issues. International cooperation. Handbook on assessment of the systems of criminal justice]. UN. New-York, 2010, 46 p.

48. Ozhegov S.I., Shvedova N.Yu. Tolkovyi slovar' russkogo yazyka [Explanatory dictionary of Russian language]. Moscow, Azbukovnik Publ., 1999, 944 p.

49. Osmina E.V. Psikhologiya subyektopolagayushego vzaimodeyistviya. Dis... dokt. psikh. nauk [Psychology of subject-supposed interaction]. Doctor of Psychology Diss. Kazan, 2012, 336 p.

50. Panferov V.N. Psikhologiya. Uchebnoe posobie [Psychology. Teaching handbook]. S. Petersburg, Piter Publ., 2013, 479 p.

51. Parygin B.D. Osnovy sotsial'no-psikhologicheskoyi teorii [Basis of social psychological theory]. Moscow, Mysl Publ., 1971, 351 p.

52. Plato. Fedr. Sochineniya v treh tomakh. Pod red. A.F. Loseva i V.F. Asmusa. [Selective works in there volumes; ed. by A.F. Losev and V.F. Asmus]. Seria: Filosofskoe nasledie. V. 2. Moscow, Mysl Publ., 1970, 611 p.

53. Sovremennye mezhdunarodnye otnosheniya i mirovaya politika. Uchebnik pod red. A.V. Torkunova [Modern international relationships and global policy. Textbook ed. by A.V. Torkunov]. Moscow, Prosveschenie Publ., 2007, 990 p. 
54. Sorokin P.A. Sistema sotsiologii. T. 2. Sotsial'naya analitika [System of sociology. Vol. 2. Social analytics]. Petrograd, Kolos Publ., 1920, 463 p.

55. Spinoza B. Izbrannye proizvedeniya: v 2 t. T. 1 [Selected works in 2 vol. V. 1]. Moscow, Gosizdat politicheskoyi literatury, 1957, 628 p.

56. Startsev M.V. Kategoriya "vzaimodeyistvie” v folosofskoyi, sotsiologicheskoyi, psikhologicheskoyi i pedagogicheskoyi literature [Category of "interaction" in philosophical, sociologic, psychologic and pedagogic literature]. Psikhologo-pedagogicheskyi jurnal Gaudeamus - Journal Gaudeamus. 2007, no. (11), pp. 49-61.

57. Stolyarenko A.V. Osnovy psikhologii. Uchebnoe posobie [Bases of psychology. Teaching handbook]. Moscow, Feniks Publ., 2010, 671 p.

58. Terekhin V.V. Nedopustimye dokazatel'stva v ugolovnom protsesse Rossii: teoreticheskie $i$ prikladnye aspekty. Dis...kand. yurid. nauk [Inadmissible evidence in criminal process: theoretical and applied aspects]. PhD in Law Diss. N. Novgorod, 2006, 214 p.

59. Filosofskiyi entsiklopedicheskiyi slovar' [Philosophical Encyclopedic Dictionary]. Moscow, Sovetskaya entsiklopediya Publ., 1983, 840 p.

60. Khrebina S.V. Ponyatie "vzaimodeystviye” kak bazovaya kategoriya pedagogicheskoyi psikhologii [Concept "interaction" as basic category of pedagogic psychology]. Izvestiya TPTU Publ., 2007, no. 13(68), pp. 155-160.

61. Tsygankov P.A. Teoriya mezhdunarodnykh otnosheniyi. Ucheb. posobie [Theory of international relationships. Teaching handbook]. Moscow, Gardariki Publ., 2008, 590 p.

62. Chernysvev O.V. Nachal'nye etapy ontogeneza vzaimodeystviya. Dis...dokt. filos. nauk [Initial stages of ontogenesis of interaction. Doctor of Philosophy Diss.]. Leningrad, 1987, 336 p.

63. Chusovitin A.G. Kontseptsiya vzaimodeystviya. Dis...dokt. filos. nauk [Concept of interaction. Doctor of Philosophy Diss.]. Novosibirsk, 1991, 322 p.

64. Schepansky Ya. Elementarnye ponyatiya sotsiologii. Pod red akad. A.M. Rumyantseva [Elementary notions of sociology; ed. by Academician A.M. Rumyantesev]. Moscow, Progress Publ., 2003, 240 p.

65. Bacon R. Opus Majus of Roger Bacon 1928. Vol. 1. Whitefish, MT: Kessinger Publishing, 2002, 444 p. 
Исмайлова С.P.

DOI: 10.25108/2304-1730-1749.iolr.2020.62.105-118

УДК 341.4

\section{Сотрудничество в системе существования}

Аннотация: Структуру системы сотрудничества составляют субъекты, объекты и корреляции между ними. К субъектам относятся физические и юридические лица, объединения (образования), не имеющие статуса юридических лиц, государственные, неправительственные, общественные или частные организации и учреждения, государства, их органы и т.п.

Объектами сотрудничества являются виды и продукты человеческой деятельности, а корреляциями - информационные коммуникации между субъектами сотрудничества.

Суть сотрудничества заключается в обмене и использовании информации для решения политических, военных, экономических, идеологических, культурных, социальных и др. вопросов человеческого бытия, представляющих интерес для его участников.

Коммуникация - эффективное синхронное и диахронное взаимодействие, цель которого состоит в передаче информации от одного субъекта к другому.

По количеству участников сотрудничество бывает многосторонним и двухсторонним, а по территориальному признаку - глобальным, надрегиональным, региональным и двухсторонним.

Правовую основу сотрудничества составляют договора (двусторонние или многосторонние, срочные или бессрочные) либо разовые контакты (обращения) сторон, не обязанных договорами.

Мы рассматриваем проблему сотрудничества в области прав человека в «чистом» виде, не отягощенную другими целями и задачами его участников, хотя подобный подход условен. Сотрудничество в области прав человека, как правило, вместе с декларированной целью защиты и соблюдения прав человека имеет и другие корни, уходящие в политические, экономические, военные и иные, более глобальные интересы участников, которые среди фигурантов сотрудничества порой и не значатся.

В идеальном же виде, сотрудничество определяется как система кооперативного взаимодействия субъектов и объектов сосуществования и коммуникаций между ними, направленного на достижение общей цели.

Ключевые слова: взаимодействие; сотрудничество; кооперация; конфликт; коммуникация; информация.

Сосуществование как вид и подсистема системы существования, обусловлено генезисом жизни на Земле и появлением первых его субъектов - человеческих особей, возникновением контактов, связей и отношений между ними. С этого времени начинается взаимодействие между субъектами сосуществования как многоаспектная форма человеческой деятельно-

\footnotetext{
- Исмайлова Севиндж Рауф кызы - докторант Академии государственного управления при Президенте Азербайджанской Республики, доктор философии права, член МОПИ, Азербайджан. E-mail: sevism@rambler.ru
} 
сти в таких её видах как экономика, политика, техника, культура и т.п., естественно в различных состояниях и степенях развития.

Понятие взаимодействия восходит к истокам философии, психологии, социологии и других наук, что обусловлено его созидательным характером и творческой ролью в системе существования.

Проблемы взаимодействия в тех или иных ракурсах рассматривались Аристотелем, Анаксагором, Платоном, Ф. Бэконом, Б. Спинозой, Г. Гегелем, И. Кантом и другими выдающимися учеными $[3 ; 4 ; 52 ; 65 ; 55 ; 11 ; 22]$, современные исследования исчисляются десятками авторов и сотнями трудов $[1 ; 2 ; 7 ; 10 ; 12 ; 13 ; 20 ; 21 ; 23 ; 24 ; 30 ; 31 ; 33 ; 35 ; 39 ; 43 ; 45 ; 49 ; 56$; $60 ; 62 ; 63]$.

Тем не менее, что естественно, при наличии столь большого количества участников, консенсус по поводу понятия и содержания взаимодействия отсутствует, порой существующие точки зрения имеют принципиальные различия.

В соответствии с целью нашего исследования, рассмотрим те из них, которые позволят выделить квинтэссенцию данного структурного элемента (подсистемы) системы существования для последующего определения и построения её других частей.

Так, рядом ученых взаимодействие в философском аспекте рассматривается в качестве категории, отражающей корреляции и взаимодействие, обусловленных степенью развития различных объектов и субъектов, существующих в едином временном поле $[7 ; 20 ; 28 ; 35]$.

Некоторые авторы считают взаимодействие особым видом непосредственного или опосредственного, внешнего или внутреннего отношения, когда свойства объекта могут проявиться и быть познанными лишь во взаимодействии с другими, а само взаимодействие выступает как интегрирующий фактор, объединяющий части в определенный тип целостности $[63$, c. $76-85]$.

Существует мнение, что структура объективного процесса взаимодействия состоит из отношения, связи и снятия, где отношение устанавливает тип изменений в виде потенциальных возможностей; связь определяет характер изменений в сфере реального существования каждого элемента; снятие фиксирует преобразование, аккумуляцию, организацию и управление проявлением свойств элементов для устойчивого развития и функционирования целого как системы [62, с. 61-64].

Согласно точки зрения В.Е. Кемерова, в понятии «взаимодействие» фиксируются «прямые» и «обратные» воздействия вещей друг на друга, обмены веществом, энергией и информацией между различными объектами, между организмами и средой, формы кооперации людей в различных ситуациях [23].

Следует особо отметить работу Р.О. Курбанова, в которой проведен историкофилософский анализ категории взаимодействие, проанализирована методологическая роль философских представлений о взаимодействии в становлении научных принципов и понятий, раскрыта её роль в формировании и развитии концепций «сила» и «поле», исследовано соотношение дальнодействия и ближнедействия, как видов взаимодействия и т.д.

Автор утверждает, что диалектической сущностью взаимодействия является единство и борьба противоположностей, разделение единого на противоположные стороны и взаимодействие между этими противоположностями есть простейшее, всеобщее и вместе с тем наиболее глубокое проявление универсального взаимодействия материальных объектов [30, c. 37]. 
В социологическом аспекте представляет интерес концепция взаимодействия Д.Г. Мида, который, исследуя социальный акт как взаимодействие, выделяет в его развитии четыре стадии: импульс, перцепцию, манипуляцию и консумацию. По его мнению, продвижение индивида последовательно по этим стадиям, связано с его переходом на новый этап развития, поскольку в процессе взаимодействия осуществляется не только механическое пополнение уже имеющегося опыта, но и его своеобразная перестройка, смещение ценностных и смысловых акцентов [42, с. 81-84].

По мнению другого представителя социологической школы Г. Блумера, взаимодействие не является простой комбинацией внешних и внутренних факторов, а состоит и из их интерпретации, дающей начало возникновению общих смыслов [8, с. 171].

Согласно представлениям П.А. Сорокина, взаимодействие людей является сознательным, представляет собой обмен ощущений, представлений, чувств, эмоций и т.д. [54, с. 5152].

Ряд ученых, считая понятия общение и взаимодействие тождественными, утверждают, что межличностное взаимодействие людей, обозначаемое как общение, почти всегда оказывается вплетенным в деятельность и выступает условием её выполнения, межсубъектное взаимодействие есть общение, которое существует в материальной и духовной формах [14; 20].

Другие рассматривают взаимодействие как одну из сторон или один из процессов общения, понимая под ним интеракцию, коллективную деятельность, непосредственно обеспечивающую взаимодействие $[2 ; 21 ; 28 ; 34 ; 51 ; 64]$.

В психологическом аспекте о сути взаимодействия, его структуре также нет единого мнения, что объясняется отраслевыми подходами к проблеме. Так, некоторые в качестве её обоснования исходят из процесса взаимодействия как такового [44; 50], другие основываются на внутренних психических процессах личности $[7 ; 24 ; 36 ; 46]$, третьи соединяют в структуре контакта личность и среду, определяя жизненное пространство в качестве единицы взаимодействия субъекта и его окружения [32] и т.д., однако в подавляющем большинстве авторы основой взаимодействия считают коммуникации между субъектами в определенных ракурсах, результатом которых является изменение установок и поведения, достижение субъектами определенного взаимопонимания и согласия.

В зависимости от субъектного критерия, в системе взаимодействия выделяются международные отношения как подсистема межгосударственных и негосударственных взаимодействий в глобальном, региональном масштабе или на уровне двухсторонних отношений [38, с. 10-11].

Однако, по поводу сущности и понятия международных отношений среди ученых также нет единого мнения. Так, М.Ю. Зеленков считает, что международные отношения - совокупность политических, экономических, идеологических, правовых, военных, дипломатических и других связей и взаимоотношений между основными субъектами мирового сообщества, к которым он относит государства, межправительственные организации (ООН, ЮНЕCКО, НАТО, ЕС, СНГ, ШОС и др.), транснациональные корпорации (IВМ и др.), международные неправительственные организации («Гринпис» и т.п.), отдельных лиц (н.п. мать Тереза) $[17$, с. 245].

Согласно другой дефиниции, международные отношения это совокупность экономических, политических, идеологических, правовых, дипломатических и иных связей и взаимо- 
отношений между государствами и системами государств, между основными классами, основными социальными, экономическими, политическими силами, организациями и общественными движениями, действующими на мировой арене, т.е. между народами в самом широком смысле этого слова [61, с. 38-39].

Практически все авторы отмечают, что тенденциями развития международных отношений как подсистемы взаимодействия являются гуманизация и демократизация. При этом под гуманизацией понимается переход к такому типу взаимодействия, которое в наибольшей степени служит интересам личности, способствует созданию максимальных возможностей для её дальнейшего развития и совершенствования, для повышения качества самой её жизни. Демократизация же считается средством построения гуманного миропорядка [6, с. 111-114; 25 , с. $93-99 ; 26$, с. $67-79 ; 29$, с. $94-105]$.

Во всех науках, изучающих проблемы взаимодействия, произведено его деление на два противоположных вида: сотрудничество и конкуренция, которые в зависимости от объективных и субъективных обстоятельств проявляются в формах кооперации и конфликта. Встречаются и другие обозначения (согласие, оппозиция, ассоциация, диссоциация и т.п.), но суть от этого не меняется.

Следует отметить, что при всех научных подходах взаимодействие в виде сотрудничества и конкуренции относится не только к отдельным личностям, но и группам, их частям, а также более структурированным образованиям.

Кооперация как форма взаимодействия означает координацию сил и средств его участников, причем может иметь место и при сотрудничестве и при конкуренции. Конфликтное взаимодействие - это связи и отношения между субъектами, однако разные цели их деятельности.

«Словарь русского языка» С.И. Ожегова в одном из значений определяет цель как, «... то к чему стремятся, что надо осуществить» [48, с. 758]. Содержание цели зависит от объективных законов действительности, потребностей общества и государства, реальных возможностей субъекта, его функций и применяемых средств [58, с. 32].

Согласно положениям философии, цель ускоряет, систематизирует процесс интеграции различных действий индивидуума в осмысленную, логическую последовательность, т.е. выступает в роли непосредственного мотива, регулятора и ориентира человеческой деятельности [59, с. 763].

Данное предназначение цели делает её мерой стандартов отношений и поведения, при которой они (стандарты) переходят в состояние аксиологических факторов, определяющих стабильность общественной системы. Реалистичность цели предполагает достижение конкретных результатов при наличии необходимых и допустимых средств в определенные промежутки времени [37, с. 12-13].

Таким образом, структуру системы сотрудничества составляют субъекты, объекты и корреляции между ними. К субъектам относятся физические и юридические лица, объединения (образования), не имеющие статуса юридических лиц, государственные, неправительственные, общественные или частные организации и учреждения, государства, их органы и т.п.

Объектами сотрудничества являются виды и продукты человеческой деятельности, а корреляциями - информационные коммуникации между субъектами сотрудничества. 
Суть сотрудничества заключается в обмене и использовании информации для решения политических, военных, экономических, идеологических, культурных, социальных и др. вопросов человеческого бытия, представляющих интерес для его участников.

Коммуникация - эффективное синхронное и диахронное взаимодействие, цель которого состоит в передаче информации от одного субъекта к другому [9, с. 14].

По количеству участников сотрудничество бывает многосторонним и двухсторонним, а по территориальному признаку - глобальным, надрегиональным, региональным и двухсторонним.

Первым в истории субъектом глобального сотрудничества государств является Организация Объединенных Наций, к надрегиональным субъектам относится Движение неприсоединения, к региональным - Европейский союз, Лига арабских государств, Организация американских государств, Организация африканского единства и др.

Правовую основу сотрудничества составляют договора (двусторонние или многосторонние, срочные или бессрочные) либо разовые контакты (обращения) сторон, не обязанных договорами.

В частности, документами, определяющими правовую основу многостороннего международного сотрудничества в области прав человека являются Устав ООН, Международный пакт о гражданских и политических правах, Международный пакт об экономических, социальных и культурных правах, Декларация о принципах международного права, касающихся дружественных отношений и сотрудничества между государствами в соответствии с Уставом Организации Объединенных Наций, Международная конвенция о ликвидации всех форм расовой дискриминации, Конвенция против пыток и других жестоких, бесчеловечных и унижающих достоинство видов обращения или наказания, Европейская конвенция о защите прав человека и основных свобод, Декларация о праве и обязанности отдельных лиц, групп и органов общества поощрять и защищать общепризнанные права человека и основные свободы и др.

Механизм сотрудничества в международных правовых документах не определен, однако анализ практики показывает, что в области прав человека он сводится к официальным и неофициальным мониторингам состояния проблемы в тех или иных странах со стороны представителей глобальных, надрегиональных и региональных участников и вынесении в зависимости от результатов соответствующих решений либо обращений, имеющих или, в основном, не имеющих правовую силу.

Как правило, инициаторами подобных мониторингов являются неправительственные организации международного или внутригосударственного уровня, такие как «Международная амнистия» («Amnesty International»), «Хьюман Райтс Вотч» («Наблюдение за правами человека»), «Репортеры без границ» и др.

Кроме того, к формам международного сотрудничества в области прав человека относятся различного рода конференции, «круглые столы» и иные подобные мероприятия, а также взаимный обмен информацией, побуждающий участников к добровольному совершению каких-либо конкретных действия [25].

В последнее время участились случаи взаимодействия (но не сотрудничества) когда один субъект с целью изменения решений или поведения другого субъекта совершает ряд действий принудительного характера, воздействует посредством различных обращений, ре- 
золюций, угрожает отлучением от членства в международных организациях, различными санкциями.

Представляется, что в этом заключается один из парадоксов сотрудничества, о которых речь пойдет в других разделах диссертации.

Условно можно выделить сотни видов сотрудничества во всех сферах бытия, которые в той или иной степени затрагивают права человека.

Перечень этот изо дня в день увеличивается, появляются все новые направления, определяются новые тенденции и вызовы. Так, П.С. Криволапов к новым вызовам в сфере международного сотрудничества в области прав человека относит терроризм и борьбу с ним, возрождение доктрины гуманитарной интервенции, проблемы этнических и религиозных конфликтов, воздействие глобализации на права человека и др. [27, с. 2-3].

Все это верно, однако, с нашей точки зрения, к сути сотрудничества в области прав человека имеет опосредственное отношение.

Представляется, что в целом международное сотрудничество в области прав человека, будучи системным образованием, как и взаимодействие, состоит из подсистем, составными элементами которых являются направления (предмет) сотрудничества, его участники и информационные коммуникации.

Схематично систему международного сотрудничества в области прав человека как подсистему международного сотрудничества можно представить следующим образом.

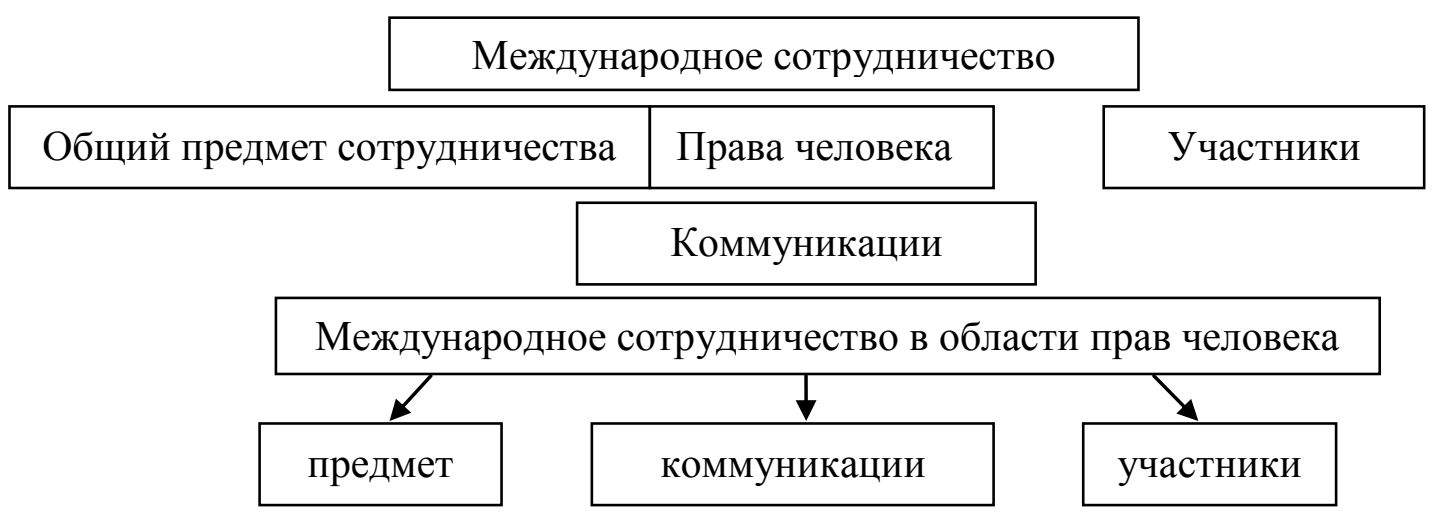

Мы рассматриваем проблему сотрудничества в области прав человека в «чистом» виде, не отягощенную другими целями и задачами его участников, хотя подобный подход условен. Далее будет показано, что сотрудничество в области прав человека, как правило, вместе с декларированной целью защиты и соблюдения прав человека имеет и другие корни, уходящие в политические, экономические, военные и иные, более глобальные интересы участников, которые среди фигурантов сотрудничества порой и не значатся.

В идеальном же виде, сотрудничество определяется как система кооперативного взаимодействия субъектов и объектов сосуществования и коммуникаций между ними, направленного на достижение общей цели.

\section{Библиография}

1. Ананьев Б.Г. Человек как предмет познания. - Л.: Изд-во Ленинградского университета, 1968. - 343 с. 
2. Андреева Г.М. Социальная психология: Учебн. - М.: Аспект Пресс, 2001. - 384 с.

3. Аристотель. Физика. - М.: Директ-Медиа, 2012. - 191 с.

4. Асмус В.Ф. Античная философия (история философии). 3-е изд. - М.: Высшая школа, 2003. - 400 c.

5. Бабурин С.П. Мир империй: Территория, государства и мировой порядок. - СПб.: Изд-во Р. Асланова и Юридический центр Пресс, 2007. - 769 с.

6. Баталов Э.Я. О философии международных отношений. - М.: Научнообразовательный форум по международным отношениям, 2009. - 132 с.

7. Бодалев А.А. Личность и общение. - М.: Международная педагогическая академия, 1995. - $328 \mathrm{c}$.

8. Блумер Г. Символический интеракционизм / Пер. с англ. А.М. Корбут. - М.: Элементарные формы, 2017. - 346 с.

9. Гавра Д.П. Основы теории коммуникации: Учебник для академического бакалавриата / 2-е изд., испр. и доп. - М.: Юрайт, 2017. - 282 с.

10. Гайнуллина А.В. К вопросу о понятии взаимодействия в отечественной психологии // Юридическая психология. - 2007, - №3. - С. 18-21.

11. Гегель Г. Наука логики: в 3-х т. Т. 2. М.: Мысль, 1971, 248 с.

12. Григорьева М.В. Взаимодействие как категория современной психологии// Ученые записки. - 2009. Т. 2. Сер. Психология. Педагогика, - № 3-4 (7-8). - С. 3-12.

13. Гринь И.Ю. Международное сотрудничество в сфере уголовного судопроизводства: Дис... канд. юрид. наук. - Санкт-Петербург, 2006. - 165 с.

14. Громкова М.Т. Психология и педагогика профессиональной деятельности: Учебное пособие для вузов. - М.: ЮНИТИ-ДАНА, 2003. - 415 с.

15. Декларация о принципах международного права, касающихся дружественных отношений и сотрудничества между государствами в соответствии с Уставом Организации Объединенных Наций от 24.10.1970 г. [Электронный ресурс]. Режим доступа: https://www.un.org/ru/documents/decl_conv/declarations/intlaw_principles.shtml (дата обращения: 18.02.2020)

16. Доленко Д.В. Современная мировая политика: Учеб. пособие. - Саранск: Изд-во Мордов. университета, 2005. - 176 с.

17. Зеленков М.Ю. Политология (базовый курс). - М.: Юридический ин-т МИИТ, 2009. $302 \mathrm{c}$.

18. Иноземцев В.Л. Россия в системе международных отношений XXI века // Международная жизнь. - 2004,- № 9-10. - С. 3-19.

19. История международных отношений и внешней политики СССР: в 3-х т. / Под ред. И.А. Кириллина. - М.: Международные отношения, 1986. - 416 с.

20. Каган М.С. Мир общения: проблемы межсубъектных отношений. - М.: Политиздат, 1988. - 319 c.

21. Казаринов Н.В., Куницын В.Н., Погольша В.М. Межличностное общение: Учебник для вузов. - СПб.: Питер, 2001. - 544 с.

22. Кант И. Сочинения в шести томах. Т. 3. - М.: 1964. - 799 с.

23. Кемеров В.Е. Взаимодействие / Центр гуманитарных технологий [Электронный ресурс]. Режим доступа: https://gtmarket.ru/concepts/7242 (дата обращения: 18.02.2020) 
24. Коломинский Я.Л. Изучение педагогического взаимодействия // Советская педагогика. - 1991, - № 10. - С. 36-42.

25. Косолапов Н.А. Исследования международных отношений, логика идей, интересов, политики // Мировая экономика и международные отношения. - 2006, - №4. - С. 93-99.

26. Косолапов Н.А. Теоретическое исследование международных отношений // Мировая экономика и международные отношения. - 1998, - № 2. - С. 67-79.

27. Криволапов П.С. Новые тенденции международного сотрудничества в области прав человека: Дис...канд. юрид. наук. - М.: 2006. - 213 с.

28. Кричевский Р.Л., Дубовская Е.М. Социальная психология малой группы: Учебное пособие для вузов. - М.: Аспект Пресс, 2001. - 318 с.

29. Кузнецова Е.С. Мировая политика и без. Анализ и прогноз в международных отношениях // Международная жизнь, 2006, № 1-2, с. 94-105.

30. Курбанов Р.О. Категория взаимодействия в философском и научном познании: Автореф. дис... докт. филос. наук. - Баку: 1989. - 52 с.

31. Ланко Д.А. Проблема сотрудничества в третьем «большом споре» в теории международных отношений//Вестник Санкт-Петербургского университета. - 2013. Сер. 6. Вып. 2. C. 92-97.

32. Левин К. Динамическая психология/Пер.с нем. и англ. Д.А. Леонтьева, Е.Ю. Патяевой. - М.: Смысл, 2001. - 572 с.

33. Левченко О.В., Мищенко Е.В. Международное сотрудничество России с государствами-участниками СНГ в сфере уголовного судопроизводства: понятие, цели, принципы // Вестник ВЭГУ. - 2014, - № 6(74). - С. 38-48.

34. Леонтьев А.А. Педагогическое общение. - М.: Знание, 1979. - 48 с.

35. Лисина М.И. Проблемы онтогенеза общения. - М.: Педагогика, 1986. - 144 с.

36. Ломов Б.Ф. Методологические и теоретические проблемы психологии. - М.: Наука, 1984. - $444 \mathrm{c}$.

37. Малько А.В., Шундиков К.В. Цели и средства в праве и правовой политике. - Саратов: Изд-во СГАП, 2003. - 296 с.

38. Малькова Т.П., Фролова М.А. Массы. Элита. Лидер. - М.: Знание, 1992. - 40 с.

39. Международная правовая помощь и иные формы сотрудничества между правоохранительными органами. ОЭСР, 2013. [Электронный ресурс]. Режим доступа: https://www.oecd.org/corruption/acn/lawenforcement/MLAandOtherFormsCooperationLaw EnforcementAgencies_RUS.pdf (дата обращения: 18.02.2020)

40. Международные отношения: теория, конфликты, организации: Учеб. пособие/Под ред. проф. П.А. Цыганкова. - М.: Альфа, 2004. - 288 с.

41. Международные отношения: виды, формы, принципы. [Электронный ресурс]. Режим доступа: https://works.doklad.ru/view/RgPucar6CdU.html (дата обращения: 14.02.2020)

42. Мид Дж. Г. Избранное: Сб. переводов / РАН. ИНИОН. Сост. и переводчик В. Г. Николаев. Отв. ред. Д. В. Ефременко. - М.: 2009. - 290 с.

43. Морозов В.А. Взаимодействие: понятие, виды и свойства// Креативная экономика. 2015. - № 9(10). - С. 1309-1318

44. Мясищев В.Н. Психология отношений. М.: Изд-во Институт практической психологии. - Воронеж: НПО МОДЭК, 1995. - 356 с. 
45. Натура А.И., Пихов А.Х-А. Международное сотрудничество в сфере уголовного судопроизводства: организационно-правовые основы, процессуальный порядок и формы взаимодействия: Учебно-практическое пособие. - М.: Изд-во Юрлитинформ, 2007. - 136 с.

46. Обозов Н.Н. Психология межличностных отношений.-Киев: Лыбидь, 1990. -192 с.

47. Общие вопросы. Международное сотрудничество: Пособие по оценке систем уголовного правосудия. ООН. - Нью-Йорк, 2010. - 46 с.

48. Ожегов С.И. и Шведова Н.Ю. Толковый словарь русского языка. - М.: Азбуковник, 1999. - 944 c.

49. Осьмина Е.В. Психология субъектополагающего взаимодействия: Дис...докт. психол. наук. - Казань, 2012. - 336 с.

50. Панферов В.Н. Психология: Учебное пособие. - СПб.: Питер, 2013. - 479 с.

51. Парыгин Б.Д. Основы социально-психологической теории. - М.: Мысль, 1971. - 351 c.

52. Платон. Федр. Сочинения в трех томах / Под общ. ред. А. Ф. Лосева и В. Ф. Асмуса. Серия: Философское наследие. Т 2. - М.: Мысль, 1970. - 611 с.

53. Современные международные отношения и мировая политика: Учебник / Под ред. А.В. Торкунова. - М.: Просвещение, 2007. - 990 с.

54. Сорокин П.А. Система социологии. Т.2: Социальная аналитика. - Петроград: Колос, 1920. - 463 с.

55. Спиноза Б. Избранные произведения: в 2-х т. Т. 1. - М.: Государственное издательство политической литературы, 1957. - 628 с.

56. Старцев М.В. Категория «взаимодействие» в философской, социологической, психологической и педагогической литературе// Психолого-педагогический журнал Гаудеамус. 2007. - № 1(11). - С. 49-61.

57. Столяренко А.В. Основы психологии: Учебн. пособие. - М.: Феникс, 2010. - 671 с.

58. Терехин В.В. Недопустимые доказательства в уголовном процессе России: теоретические и прикладные аспекты: Дис... канд. юрид. наук. - Н. Новгород, 2006. -214 с.

59. Философский энциклопедический словарь. - М.: Советская энциклопедия, 1983. $840 \mathrm{c}$.

60. Хребина С.В. Понятие «взаимодействие» как базовая категория педагогической психологии // Известия ТРТУ. - 2007. - № 13(68). - С. 155-160.

61. Цыганков П.А. Теория международных отношений: Учеб. пособие. - М.: Гардарики, 2008. - 590 c.

62. Чернышев О.В. Начальные этапы онтогенеза взаимодействия: Дис... докт. филос. наук. - Л.: 1987. - 336 с.

63. Чусовитин А.Г. Концепция взаимодействия: Дис... докт. филос. наук. - Новосибирск: 1991. - 322 с.

64. Щепаньский Я. Элементарные понятия социологии/Под общ. ред. академика А.М. Румянцева. - М.: Изд-во Прогресс, 2003. - 240 с.

65. Bacon R. Opus Majus of Roger Bacon 1928. Vol. 1. Whitefish, - MT: Kessinger Publishing, 2002. - 444 p. 